\title{
Teaching Materials Needs: Student Worksheets in Exposition Text Learning
}

\author{
Wulanti Sagitari ${ }^{*}$, Mulyadi Eko Purnomo², Ernalida ${ }^{3}$ \\ 1,2,3 The Postgraduate Student Program of Indonesian Language Education, Universitas Sriwijaya, Palembang, Indonesia
}

\section{A R T I C L E I N F O}

Article history:

Received April 24, 2021

Revised April 25, 2021

Accepted September 30, 2021

Available online November 25, 2021

\section{Kata Kunci :}

Berpikir Tingkat Tinggi, Lembar Kerja Siswa, Pendekatan Saintifik

Keywords:

Higher-Order Thinking, Student Worksheet, Scientific Approach

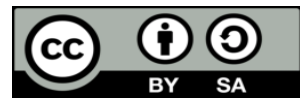

This is an open access article under the $\underline{C C}$ BY-SA license.

Copyright (ㄷ) 2021 by Author. Published by Universitas Pendidikan Ganesha

\begin{abstract}
A B S T R A K
Guru bahasa Indonesia di sekolah kekurangan bahan ajar. Bahkan guru tidak memiliki bahan ajar yang berorientasi HOTS. Hal ini akan berdampak pada siswa yang kesulitan dalam belajar karena tidak memiliki sumber belajar. Pendidik profesional harus mampu mengembangkan bahan ajar untuk mengatasi tujuan pembelajaran Kurikulum 2013 dalam situasi pembelajaran apapun. Kesiapan guru untuk melaksanakan proses belajar mengajar dapat dibantu dengan menerapkan bahan ajar yang sesuai dengan kurikulum 2013. Penelitian ini bertujuan untuk melakukan survei analisis kebutuhan dari berbagai tahap penelitian dan tahap pengembangan untuk mengembangkan dan memvalidasi produk serta menentukan bahan ajar yang sesuai. Tahapan penelitian dan pengembangan yang diterapkan terdiri dari identifikasi proses pembelajaran, analisis hasil belajar yang ditargetkan, dan analisis peserta didik dan kebutuhannya. Subyek penelitian terdiri dari siswa kelas $X$ dengan populasi 185 peserta didik dan 2 guru bahasa Indonesia. Jumlah sampel sebanyak 28 peserta didik atau $15 \%$ dari populasi. Teknik pengumpulan data yang pertama adalah angket kebutuhan peserta didik dan wawancara. Berdasarkan temuan dan pembahasan, LKS yang direkomendasikan oleh peneliti adalah LKS eksposisi dengan pendekatan saintifik plus. Dengan LKS ini, peserta didik dapat melatih keterampilannya dan mencari informasi yang akurat untuk diungkapkan dalam teks eksposisinya. Di sisi lain, guru juga dapat memantau dan memfasilitasi siswa untuk mengkonstruksi pengetahuan mereka tentang teks.
\end{abstract}

\section{A B S T R A C T}

Indonesian language teachers in schools lack teaching materials. Even teachers don't have HOTS-oriented open materials. It will impact students who have difficulty in learning because they do not have learning resources. Professional educators must be able to develop teaching materials to address the learning objectives of the 2013 Curriculum in any learning situation. The readiness of teachers to carry out the teaching and learning process can be assisted by applying teaching materials that are by the 2013 curriculum. This study aims to conduct a needs analysis survey from various research and development stages to develop and validate products and determine appropriate teaching materials. The stages of research and development are applied from the learning process, analysis of targeted learning outcomes, and analysis of students and their needs. The research subjects consisted of class X students with a population of 185 students and 2 Indonesian language teachers. The number of samples is 28 students, or $15 \%$ of the population. The first data collection technique is a questionnaire of student needs and interviews. Based on the findings and discussion, the LKS recommended by researchers is the exposition LKS with a scientific plus approach. Students can practice it and find accurate information for the exposition text with this worksheet. On the other hand, teachers can also unite and facilitate students to construct their knowledge of the text.

\section{INTRODUCTION}

Preparation of quality teaching and learning activities is the key to achieving learning objectives. This preparation is of high quality because it is supported by a good learning component (Heong et al., 2011; Stone et al., 2013; Syauqi et al., 2020). The learning components include learning objectives, materials or materials, strategies, media, and learning evaluations (Hadar \& Tirosh, 2019; Permana \& Nourmavita, 2017; Yuanta, 2020). The linkages between these learning components require teachers to always consider the needs of students in the learning process, especially with distance learning conditions like today. Teaching materials are one of the essential learning components to be developed by teachers so that teaching and learning activities remain effective and productive (Arizona et al., 2020; Indrianto \& Kurniawati, 2020; Wibowo et al., 2017). Teaching material is any kind of material used to facilitate the instructor in teachinglearning activities. The forms of the teaching materials are such as handouts, books, worksheets, brochures, leaflets, wall charts, figures, models, or mock-up (Dini, Nurhayati, 2019; Fonda \& Sumargiyani, 2018; 
Parvareshbar \& Ghoorchaei, 2016). A teaching material contains a set of materials arranged systematically so it could realize a situation or an atmosphere to allow learners to learn properly (Desnita \& Susanti, 2017; Pratama et al., 2019). In the current learning process, the 2013 curriculum emphasizes a scientific approach. It applies scientific principles in a learning process. The scientific approach is purposed to provide understanding for learners to know, understand, and practice what they have learned scientifically (Fernández-Gutiérrez et al., 2020; Hasbullah, 2018; Izati et al., 2018). This approach teaches the learners to seek information from various sources and various processes, such as observing, inquiring, experimenting, managing, presenting, concluding, and creating for all lessons (Meilani et al., 2020; Nur et al., 2016; Suryani et al., 2019). Learners should be prepared with higher-order thinking skills to reach the 2013 curriculum objectives. Thus, they could apply the new information, new knowledge, and background knowledge; and manipulate the information to cover various answers in a new situation. Higher-order thinking skill learners could differ facts and opinions; identify the relevant information; solve problems, and conclude the analyzed information (Hamdi et al., 2018; Johanns et al., 2017; Kurniawan, 2019).

Based on the interviews with two Indonesian language teachers in the school, the teaching materials were limited. They even did not have HOTS-oriented teaching materials. At the present day, distance learning made teachers had difficulties to conduct the learning process especially when they provided effective tasks. Thus, the researchers were motivated to investigate the learners' and teachers' needs for the appropriate teaching materials. This research attempted to develop teaching material in the form of student worksheets with a scientific plus for exposition text in the tenth grade of Public Senior High School 3 Prabumulih. It was an effort to improve the students' HOTS. However, before conducting the stages of the research and development, this current research attempted to describe the learners' and teachers' needs toward the student worksheet based on scientific plus for exposition text to improve the tenth graders' HOTS. The higher-order thinking skill is a thinking process that involves mental activity to explore a complex, reflective, and creative experience (Dinatha \& Kua, 2019; Gunada et al., 2021; Zulfiani et al., 2020). It is done consciously to reach the objectives, to obtain knowledge under the levels of analytics, synthetics, and evaluation. Learners should improve their HOTS that could be done in various manners, such as providing qualified teaching material at school (Anwar et al., 2020; Kurniawan, 2019; Ndiung \& Jediut, 2020). Therefore, educators could combine various learning models to motivate the learners' learning interest with scientific activities. HOTS development for learners could facilitate the knowledge transition process and improve their responsibilities and functions in their community (Marshel \& Ratnawulan, 2020; Zulfiani et al., 2020). HOTS could be realized in an integrated learning and assessment process. HOTS question item development should follow the applied principles in terms of the writing systematics and the rules based on the cognitive levels of the learners (Kurniati et al., 2016; Wartono et al., 2018; Widana, 2020). Educators could make questions with operational verbs that are included in the cognitive analysis domain, such as analyzing, detecting, measuring, or reviewing. The evaluative-cognitive domain contains several operational verbs, such as comparing, assessing, predicting, and interpreting. Higher order thinking should be emphasized on student worksheets.

The student worksheet or known as LKPD is a part of the learning instrument. In the education world, there are several instruments for learning activities, such as syllabus, lesson plan, student worksheet, etc (Diani \& Nurhayati, 2019; Indah, 2020). The learning process requires a learning instrument as the important component developed by the educators for the learners. A student worksheet or LKPD refers to sheets containing tasks to work on by the learners (Nurliawaty et al., 2017; Pentury et al., 2019). A student worksheet contains activities and tasks to make learners actively learn and take meaningful matters from the learning process. Student worksheet is a part of printed media and becomes the teaching material. Thus, it could be used in the teaching-learning process (Marshel \& Ratnawulan, 2020; Muzayyanah et al., 2020). Student worksheets may take form into learners' understandings used to conduct an investigation or solve problems. A student worksheet may take form into understanding to do exercises and to develop cognitive aspects. It may also take form into the guideline to develop all learning aspects in the forms of experimental or demonstrative guidelines. Previous research found that the implementation of student worksheets for writing text could improve the learners' outcomes (Agitsna et al., 2019). Learning with Higher-Order Thinking skill could make learners' thinking critically and creatively and develop the learners' characters while thinking. The researchers also stated that HOTS were needed by learners.

Based on the experts' arguments about student worksheets, it could be concluded that student worksheets referred to printed media in the form of sheets. They were used by learners to work on their tasks, to measure their understanding, to determine the cognitive aspect development, and to determine all improvements of learning aspects. Based on the conclusion, a worksheet facilitated learners during their learning activities. It provided them not only the explanation but also guidelines to do learning activities, such as observing, experimenting, identifying, creating tables, and noting their research results on the worksheet. This research aims to conduct a need analysis survey from various research stages and 
development stages to develop and validate the product and to determine what kind of teaching materials. Theoretically, this study about the learners' and teachers' needed toward the student worksheet is expected to contribute to educational science. It is specifically for student worksheets about exposition text. Practically, the findings of this research could be useful for learners, educators, schools, and researchers.

\section{METHODS}

This research was a survey of need analysis. It was originally the part of a research and development to develop and validate the products, such as teaching materials, textbooks, modules, and worksheets. The research and development study should be carried out systematically, started from the designing, developing, evaluating, and producing a product based on internal consistency and effectiveness criteria (Hakim et al., 2018). Therefore, this research would develop a student worksheet about exposition text. It was designed, developed, evaluated, validated, and checked to determine the potential effects via a systematic research procedure. This analysis stage was done to determine what steps to take in an R\&D study (Azhari \& Agus, 2016). Therefore, this stage could be considered as a qualitative research stage. It aimed to obtain the evidence or findings to be reviewed, interpreted, and explained. In this qualitative research, the researchers should keep the findings and the investigation process coherently (Çelik et al., 2020; Coombs, 2017).Therefore, this research adopted the stages of need identification by (Diani \& Nurhayati, 2019). The applied stages of a research and development study consist of instructional process identification, the analysis of the targeted learning outcomes, and the analysis of the learners and their needs. The research location was in Public Senior High School 3 Prabumulih, Southern Sumatera Province. The subjects consisted of tenth graders with a population of 185 learners and 2 Indonesian language teachers. The numbers of the sample were 28 learners or $15 \%$ of the population (Igwe et al., 2020; Triyono, 2018).

The first technique to collect the data was a questionnaire about the learners' needs in learning exposition text, their hopes to learn it, and the expected worksheet. The obtained information would be used as considerations in developing the students' worksheet about exposition text. The next technique was an interview. An interview is a dialog conducted by the interviewer to get information from the interviewee (Arikunto, 2010). The interview was used as a complement to the questionnaire results. It was done with the teachers and the learners. The interview was used to clarify unclear information from the questionnaire results. The questionnaire results obtained from the teachers and learners were processed objectively. They were then described. The interview results were processed objectively, described, and concluded. The conclusion was used to complement the test data as the revision of the developed student worksheets. The technique used to analyze the data is descriptive qualitative.

\section{RESULT AND DISCUSSION}

\section{Results}

Based on the interview results with two Indonesian language teachers of the school, they argued that writing exposition text had a purpose to propose something personal. It contained opinions or arguments of the writer to be delivered and accepted by readers. Therefore, it was the instructional purpose of the writing. Writing an exposition text should cover some skills to make the text readable. Based on the interview results with the teachers, they argued that the skills to achieve were such as sharing an opinion, arguing, and concluding. They found that writing exposition text required background knowledge that might be obtained by reading, managing information, and expressing them. The next skill dealt with higherorder thinking skills. It could be seen from the exposition text structures that required higher-order thinking skills. From the identification results and the skill analysis, the learners needed a worksheet that provided them various information, managed information into an argument, managed information into opinion, and arranged the conclusion to persuade readers. It required higher-order thinking skills because the obtained information would not be only written but also understood and expressed based on the needs. However, the learners were found to feel bored due to the out-of-date model of the teachers to deliver the materials. It could be seen from the learners' characteristics that got more advanced. They could have found the information that they needed. They also thought that the needed information could not be always uniform but they needed pro and contra information (the interview result with the learners).

From the analysis show that, the learners had the interest to search the information autonomously. The result also showed that the highest information needs were pro and cont information, other authors' arguments, and definitions. From the analysis, the learners needed various text genres to enrich their initial knowledge. It had a function as their writing preparations. With this information source, the learners admitted they would not be easily bored due to limited information (the interview result with the learners). 
The analysis shows that learners needed a scientific approach to learn. This approach applies the scientific principles for the learning process. The scientific stages contain finding problems, formulating problems, proposing hypotheses, collecting data, analyzing data, and concluding.

The learners would be asked to construct their knowledge, understanding, and skills from the learning process autonomously. On the other hand, the educators would direct, empower, and enrich them with what they had learned. Conceptually, this approach was more humanism. It provided spaces for learners to develop based on their potentials. In this approach, learners become the learning center instead of the learning object. Based on the interview with the learners, they needed sufficient time to write exposition text. The reason was; they had to find sufficient information to strengthen their argument and to invite the readers. They preferred writing outside of the classrooms, such as at the library or home. They also found that learners would think and write better when they did the activities outside of classrooms, such as at home. From the descriptions of the learners' needs, the teachers argued they needed a worksheet that could monitor what the learners read. They also argued that the worksheet should allow learners to obtain information from various resources and apply a scientific approach to reach better higher-order thinking skills. They needed a worksheet that could accompany the writing exposition text process instead of a worksheet to check the product.

\section{Discussion}

The teachers' statements proved that they already had sufficient knowledge about the writing purpose and were in line with the 2017 revised version of 2013 curriculum instruction for tenth graders (Darmaji et al., 2019; Hutama, 2016; Utami et al., 2018). This finding was also found in the previous studies, found that exposition text was a text that provided information and elaborated a matter to persuade the readers (Fitri \& Afnita, 2020; Jamhar et al., 2020; Juariah et al.,2020; Ridodo et al., 2015). They also found a correlation between reading and writing skills of exposition text. The teachers' statements were in line with the study of (Jultia et al., 2019; Sulastin et al., 2019; Yodeska \& Nursaid, 2020). They found that learning to write exposition text could improve the learners' skills to argue, share opinions, think logically, creatively, systematically, and persuasively. Besides that, the skill to obtain was reading skill. This finding was also found, a correlation between writing exposition text and reading skills (Mustika \& Susanti, 2020; Muzayyanah et al., 2020).

Thinking is a mental activity when an individual is engaged with a problem or situation to solve. The thinking skills could be classified into lower and higher thinking order skills (Amir \& Wardana, 2018; Rahayuni, 2016). Higher-order thinking skill is defined as how to use the mind broadly to find new challenges. Higher-order thinking skills demand the individuals apply new information or previous knowledge and manipulate them to cover any answer possibilities in a new situation. The higher-order thinking skill learners could differ facts and opinions; identify the relevant information; solve problems, and conclude the analyzed information (Kurniati et al., 2016; Marshel \& Ratnawulan, 2020). Higher-order thinking skill involves mental operations, such as classification, induction, deduction, and reasoning. Higher-order thinking skill is a thinking process that involves mental activity to explore a complex, reflective, and creative experience (Anisah \& Lastuti, 2018; Pratiwi et al., 2017). It is done consciously to reach the objectives, to obtain knowledge under the levels of analytics, synthetics, and evaluation. Learners would need various information from various genres from various sources to write. It was important because learners had different perspectives on a given topic while writing. It was also important for writing exposition text because the text aimed to persuade readers with arguments. A scientific approach is needed because it makes learners able to improve their thinking skills. This approach also focuses on progress and development rather than the product. Previous research found that scientific approach could encourage teachers to act as facilitators (Djaelani, 2019; Hariyatmi et al., 2019; Masitoh \& Prasetyawan, 2020); Saryantono \& Nurdiana, 2018; Setyarini, 2018; Wirapathi et al., 2019; Yanto, 2019). Thus, the learning targets were the learners.

Therefore, the researchers recommended the Scientific Plus Exposition Text Writing. The stages to conduct were Providing examples related to the topics for the learners to write; Asking the learners to read exposition text then giving them chance to ask about the text Allowing learners to ask about the text; Providing chances for learners to find various information about exposition text from various sources; Explaining the text types: the objectives, uses, and the social context; Explaining the organizational structures of the text; Identifying the organizational structures and the language features of the text; Asking the learners to write exposition text based on the prepared scaffolding; 8) Correcting and revising the writing; Asking the learners to write the text individually; Asking the learners to broaden and analyze the text critically by reducing or adding the stages of the text; Creating an exposition text by expressing the obtained ideas. 


\section{CONCLUSION}

With this student worksheet, the learners could train their skills and seek accurate information to be expressed in their exposition text. On the other hand, the teachers could also monitor and facilitate the learners to construct their knowledge about the text. Based on the findings and discussion, the recommended student worksheet by the researchers was an exposition-student worksheet with a scientific plus approach.

\section{REFERENCES}

Agitsna, L. D., Wahyuni, R., Friansah, D., \& Friansah, D. (2019). Pengembangan Lembar Kerja Siswa Berbasis Problem Based Learning Pada Materi Bangun Ruang Sisi Datar Kelas Viii Smp Negeri 11 Lubuklinggau. AKSIOMA: Jurnal Program Studi Pendidikan Matematika, 8(3), 429-437. https://doi.org/10.24127/ajpm.v8i3.2360.

Amir, M. F., \& Wardana, M. D. K. (2018). Pengembangan domino pecahan berbasis open ended untuk meningkatkan kemampuan berpikir kreatif siswa sd. AKSIOMA: Jurnal Program Studi Pendidikan Matematika, 6(2), 178. https://doi.org/10.24127/ajpm.v6i2.1015.

Anisah, \& Lastuti, S. (2018). Pengembangan Bahan Ajar berbasis HOTS untuk Meningkatkan Kemampuan Pemecahan Masalah Matematis Mahasiswa. Kreano: Jurnal Matematika Kreatif-Inovatif, 9(2), 191197. https://doi.org/10.15294/kreano.v9i2.16341.

Anwar, Y., Selamet, A., Huzaifah, S., \& Madang, K. (2020). Training in developing higher-order thinking based online test instrument for biology teachers in Sekayu City. Journal of Community Service and Empowerment, 1(3), 150-155. https://doi.org/10.22219/jcse.v1i3.12241.

Arikunto, S. (2010). Prosedur Penelitian: Suatu Pendekatan Praktik. Jakarta: Rineka Cipta.

Arizona, K., Abidin, Z., \& Rumansyah, R. (2020). Pembelajaran Online Berbasis Proyek Salah Satu Solusi Kegiatan Belajar Mengajar Di Tengah Pandemi Covid-19. Jurnal Ilmiah Profesi Pendidikan, 5(1). https://doi.org/10.29303/jipp.v5i1.111.

Azhari, M., \& Agus, F. (2016). Analisa kebutuhan sistem informasi manajemen perusahaan kayu ukir (SIMPKU) (study kasus CV. Embed). Informatika Mulawarman : Jurnal Ilmiah Ilmu Komputer, 11(1), 49. https://doi.org/10.30872/jim.v11i1.204.

Çelik, H., Baykal, N. B., \& Memur, H. N. K. (2020). Qualitative data analysis and fundamental principles. Journal of Qualitative Research in Education, 8(1), 379-406. https://doi.org/10.14689/issn.21482624.1.8c.1s.16m.

Coombs, C. (2017). Coherence and transparency: some advice for qualitative researchers. Production, 27, 18. https://doi.org/10.1590/0103-6513.006817.

Darmaji, D., Kurniawan, D. A., Astalini, A., Kurniawan, W., Anwar, K., \& Lumbantoruan, A. (2019). Students' perceptions of electronic's module in physics practicum. Journal of Education and Learning (EduLearn), 13(2), 288-294. https://doi.org/10.11591/edulearn.v13i2.13005.

Desnita, D., \& Susanti, D. (2017). Science Process Skills-Based Integrated Instructional Materials to Improve Student Competence Physics Education Prepares Learning Plans on Teaching Skills Lectures. Jurnal Penelitian \& Pengembangan Pendidikan Fisika, 3(1), 35. https://doi.org/10.21009/1.03105.

Diani, D. R., \& Nurhayati, D. S. (2019). Pengembangan Lembar Kerja Peserta Didik (LKPD) Menulis Cerpen Berbasis Aplikasi Android. Jurnal Bahasa, Sastra, Dan Pengajarannya, 7, 2. https://doi.org/10.20961/basastra.v7i2.37800.

Dinatha, N. M., \& Kua, M. Y. (2019). Pengembangan Modul Praktikum Digital Berbasis Nature of Science (Nos) Untuk Meningkatkan Higher Order Thinking Skill (Hots). Journal of Education Technology, 3(4), 293. https://doi.org/10.23887/jet.v3i4.22500.

Djaelani, A. K. (2019). Efektivitas penerapan pendekatan saintifik (scientific learning) terhadap kemampuan berpikir kritik dan pemecahan masalah matematika. Jurnal Teknologi Pendidikan Madrasah, 2(1), 97-114. https://doi.org/10.5281/zenodo.2576766.

Fernández-Gutiérrez, M., Gimenez, G., \& Calero, J. (2020). Is the use of ICT in education leading to higher student outcomes? Analysis from the Spanish Autonomous Communities. Computers and Education, 157, 103969. https://doi.org/10.1016/j.compedu.2020.103969.

Fitri, M., \& Afnita. (2020). Korelasi keterampilan membaca pemahaman dan keterampilan menulis teks eksposisi siswa kelas VII SMP Negeri 11 Padang. Jurnal Penelitian Bidang Pendidikan, 26(2), 77-81. https://doi.org/http://dx.doi.org/10.24114/jpbp.v26i2.17925.

Fonda, A., \& Sumargiyani, S. (2018). The Developing Math Electronic Module With Scientific Approach Using Kvisoft Flipbook Maker Pro For Xi Grade Of Senior High School Students. Infinity Journal, 7(2), 109122. https://doi.org/10.22460/infinity.v7i2.p109-122. 
Gunada, I. W., Ayub, S., Doyan, A., Verawati, N. N. S. P., \& Hikmawati, H. (2021). Pengembangan Buku Ajar Sejarah Fisika Berbasis Higher Order Thingking Skill (HOTS). Jurnal Pendidikan Fisika Dan Teknologi, 7(1), 59-65. https://doi.org/10.29303/JPFT.V7I1.2767.

Hadar, L. L., \& Tirosh, M. (2019). Creative Thinking in Mathematics Curriculum: An Analytic Framework. Thinking Skills and Creativity, 33(September 2018), 100585. https: //doi.org/10.1016/j.tsc.2019.100585.

Hakim, M. L., Asrowi, \& Akhyar, M. (2018). Pengembangan Multimedia Interaktif Mata Pelajaran Bahasa Arab Materi Profesi bagi Siswa Kelas VIII SMP IT Al-Huda Wonogiri. JTP - Jurnal Teknologi Pendidikan, 20(3), 249-263. https://doi.org/10.21009/jtp.v20i3.9537.

Hamdi, S., Suganda, I. A., \& Hayati, N. (2018). Developing higher-order thinking skill (HOTS) test instrument using Lombok local cultures as contexts for junior secondary school mathematics. Research and Evaluation in Education, 4(2), 126-135. https://doi.org/10.21831/reid.v4i2.22089.

Hariyatmi, Septiety, D. D., \& Wijayanti, R. (2019). Implementasi pendekatan saintifik guru biologi SMA di Boyolali. Proceeding Biology Educational Conference, 16(1), 1-8.

Hasbullah, H. (2018). Peningkatan Hasil Belajar Kognitif Biologi Menggunakan Model Problem Base Learning Berbasis Powtoon Siswa Kelas Xii Ipa 7 Sma N 1 Metro Semester Ganjil Tahun Pelajaran 2017/2018. BIOEDUKASI Jurnal Pendidikan Biologi), 9(2), 124. https://doi.org/10.24127/bioedukasi.v9i2.1623.

Heong, Y. M., Othman, W. B., Yunos, J. B. M., Kiong, T. T., Hassan, R. Bin, \& Mohamad, M. M. B. (2011). The Level of Marzano Higher Order Thinking Skills among Technical Education Students. International Journal of Social Science and Humanity, 1(2), 121-125. https://doi.org/10.7763/ijssh.2011.v1.20.

Hutama, F. S. (2016). Pengembangan Bahan Ajar IPS Berbasis Nilai Budaya Using Untuk Siswa Sekolah Dasar. JPI (Jurnal Pendidikan Indonesia), 5(2), 113. https://doi.org/10.23887/jpiundiksha.v5i2.8359.

Igwe, Bassey, \& Oyah. (2020). Comparative analysis of the efficiency of simple random sampling and stratified random sampling techniques using data from 2006 population figures of the six south states of Nigeria. International Journal of Advanced Research, 8(3), 1056-1064. https://doi.org/10.21474/ijar01/10724.

Indah, P. (2020). Development of HOTS (High Order Thinking Skill) Oriented Learning Through Discovery Learning Model to Increase The Critical Thinking Skill of High School Students. International Journal of Chemistry Education Research, 3(3). https://doi.org/10.20885/ijcer.vol4.iss1.art4.

Indrianto, N., \& Kurniawati. (2020). Developing Pop-Up Book Based Media To Improve The First Grader Students' Learning Achievement on The Theme of Natural Event of Min 4 Jember. Jurnal Pendidikan Dasar Nusantara, 5(2), 279-291. https://doi.org/10.29407/jpdn.v5i2.13836.

Izati, S. N., Wahyudi, \& Sugiyarti, M. (2018). Project Based Learning Berbasis Literasi untuk Meningkatkan Hasil Belajar Tematik. Jurnal Pendidikan: Teori, Penelitian, Dan Pengembangan, 3(9), 1122-11271127. https://doi.org/10.17977/jptpp.v3i9.11508.

Jamhar, R., Mboka, I., \& Sidik, S. (2020). Peningkatan kemampuan menulis teks eksposisi menggunakan metode collaborative writing. Jurnal Ilmiah Iqra', 14(1), 1. https://doi.org/10.30984/jii.v14i1.1028.

Johanns, B., Dinkens, A., \& Moore, J. (2017). A systematic review comparing open-book and closed-book examinations: Evaluating effects on development of critical thinking skills. Nurse Education in Practice, 27, 89-94. https://doi.org/10.1016/j.nepr.2017.08.018.

Juariah, D., Arifin, E. Z., \& Suendarti, M. (2020). Pengaruh minat baca dan penguasaan kosakata terhadap kemampuan menulis teks eksposisi. Diskursus: Jurnal Pendidikan Bahasa Indonesia, 3(01), 27. https://doi.org/10.30998/diskursus.v3i01.6681.

Jultia, W. O., Sahlan, \& Hanafi, F. (2019). Kemampuan menulis teks eksposisi siswa kelas VIII SMP Negeri 1 Duruka. Jurnal Bastra (Bahasa Dan Sastra), 4(3). https://doi.org/10.36709/jb.v4i3.10754.

Kurniati, D., Harimukti, R., \& Jamil, N. A. (2016). Kemampuan berpikir tingkat tinggi siswa SMP di Kabupaten Jember dalam menyelesaikan soal berstandar PISA. Jurnal Penelitian Dan Evaluasi Pendidikan, 20(2), 142-155. https://doi.org/10.21831/pep.v20i2.8058.

Kurniawan, G. E. (2019). Pengembangan Modul Pembelajaran Berbasis Model Problem Solving Untuk Meningkatkan High Order Thinking Skill Pada Pelajaran Ipa Pokok Bahasan Fluida Statis Siswa Kelas Viii Smp N 7 Cirebon Tahun Ajaran 2018/2019. Mangifera Edu, 4(1), 63-72. https://doi.org/10.31943/mangiferaedu.v4i1.531.

Marshel, J., \& Ratnawulan. (2020). Analysis of Students Worksheet (LKPD) integrated science with the theme of the motion in life using integrated connected type 21st century learning. Journal of Physics: Conference Series, 1481(1). https://doi.org/10.22219/jppg.v1i1.12462. 
Masitoh, L. F., \& Prasetyawan, E. (2020). The effectiveness of scientific approach with open-ended problem based learning worksheet viewed from learning achievement, creative thinking ability, interest, and mathematics self-efficacy. Daya Matematis: Jurnal Inovasi Pendidikan Matematika, 7(3), 292. https://doi.org/10.26858/jds.v7i3.11874.

Meilani, D., Dantes, N., \& Tika, I. N. (2020). Pengaruh Implementasi Pembelajaran Saintifik Berbasis Keterampilan Belajar dan Berinovasi 4C terhadap Hasil Belajar IPA dengan Kovariabel Sikap Ilmiah pada Peserta Didik Kelas V SD Gugus 15 Kecamatan Buleleng. Jurnal Elementary: Kajian Teori Dan Hasil Penelitian Pendidikan Sekolah Dasar, 3(1), https://doi.org/10.31764/elementary.v3i1.1412.

Mustika, S. W., \& Susanti. (2020). Pengembangan lembar kerja peserta didik (LKPD) berbasis Higher Order Thinking Skill (HOTS) praktikum akutansi lembaga. Jurnal Pendidikan Ekonomi, 13(2), 409-414. https://doi.org/https://dx.doi.org/10.17977/UM014v13i22020p125.

Muzayyanah, A., Wijayanti, A., \& Ardiyanto, A. (2020). Pengembangan lembar kerja peserta didik (LKPD) tematik berbasis HOTS (Higher Order Thinking Skill) kelas IV Sekolah Dasar. Jurnal Pijar Mipa, 15(5), 452-457. https://doi.org/10.29303/jpm.v15i5.1712.

Ndiung, S., \& Jediut, M. (2020). Pengembangan instrumen tes hasil belajar matematika peserta didik sekolah dasar berorientasi pada berpikir tingkat tinggi. Premiere Educandum : Jurnal Pendidikan Dasar Dan Pembelajaran, 10(1), 94. https://doi.org/10.25273/pe.v10i1.6274.

Nur, S., Pujiastuti, \& Rahman. (2016). Efektivitas Model Problem Based Learning (PBL) terhadap Hasil Belajar Mahasiswa Prodi Pendidikan Biologi Universitas Sulawesi Barat. Jurnal Saintifik, 2(2), 133141. https://doi.org/10.31605/saintifik.v2i2.105.

Nurliawaty, L., Mujasam, M., Yusuf, I., \& Widyaningsih, S. W. (2017). Lembar Kerja Peserta Didik (LKPD) Berbasis Problem Solving Polya. JPI (Jurnal Pendidikan Indonesia), 6(1), 72-81. https://doi.org/10.23887/jpi-undiksha.v6i1.9183.

Parvareshbar, F., \& Ghoorchaei, B. (2016). The Effect of Using Short Stories on Vocabulary Learning of Iranian EFL Learners. Theory and Practice in Language Studies, 6(7), 1476. https://doi.org/10.17507/tpls.0607.20.

Pentury, H., Festiyed, Hamdi, \& Yurnetti. (2019). Pembuatan Lembar Kerja Peserta Didik (LKPD) Berbasis Model Discovery Learning Pada Materi Gelombang Berbantuan Aplikasi Android Untuk Kelas XI SMA/MA. Pillar of Physics Education, 12(4), 617-624. https://doi.org/10.24036/7144171074.

Permana, E. P., \& Nourmavita, D. (2017). Pengembangan Multimedia Interaktif Pada Mata Pelajaran Ipa Materi Mendeskripsikan Daur Hidup Hewan Di Lingkungan Sekitar Siswa Kelas Iv Sekolah Dasar. Jurnal PGSD, 10(2), 79-85. https://doi.org/10.33369/pgsd.10.2.79-85.

Pratama, F., Firman, \& Neviyarni. (2019). Pengaruh Motivasi Belajar IPA Siswa Terhadap Hasil Belajar Di Sekolah Dasar Negeri 01. Jurnal Ilmu Pendidikan, 1(3), 280-286. https://doi.org/10.31004/edukatif.v1i3.63.

Pratiwi, P. H., Nur, H., \& Martiana, A. (2017). Pengembangan Modul Mata Kuliah Penilaian Pembelajaran Sosiologi Berorientasi Hots. Jurnal Cakrawala Pendidikan, 36(2), 201-209. https://doi.org/10.21831/cp.v36i2.13123.

Rahayuni, G. (2016). Hubungan Keterampilan Berpikir Kritis Dan Literasi Sains Pada Pembelajaran Ipa Terpadu Dengan Model Pbm Dan Stm. Jurnal Penelitian Dan Pembelajaran IPA, 2(2), 131. https: //doi.org/10.30870/jppi.v2i2.926.

Ridodo, M., Samhati, S., \& Suliani, N. N. W. (2015). Pembelajaran menulis teks eksposisi siswa kelas X SMA Negeri 3 Bandar Lampung. Jurnal Kata (Bahasa, Sastra, Dan Pembelajarannya), April, 1-12.

Saryantono, B., \& Nurdiana, A. (2018). Pelatihan pendekatan saintifik dalam pembelajaran matematika bagi guru SMA Adiguna Bandar Lampung. Adiguna: Jurnal Pengabdian Dan Pemberdayaan Masyarakat, 3(1), 25-30. https://doi.org/10.1093/oseo/instance.00191269.

Setyarini, M. N. (2018). The implementation of scientific approach with project-based learning in teaching recount text. English Education Journal, 8(3), 388-394. https://doi.org/10.36597/jellt.v2i1.2708.

Stone, R., Cooper, S., \& Cant, R. (2013). The Value of Peer Learning in Undergraduate Nursing Education: A Systematic Review. ISRN Nursing, 2013(i), 1-10. https://doi.org/10.1155/2013/930901.

Sulastin, Ana, H., \& Sahlan. (2019). Kemampuan memahami struktur teks eksposisi siswa kelas VIII SMP Negeri 2 Wadaga Kabupaten Muna Barat. Jurnal Bastra (Bahasa Dan Sastra), 53(9), 1689-1699. http://dx.doi.org/10.36709/jb.v4i4.14205.

Suryani, N. K., Renda, N. T., \& Wibawa, I. M. C. (2019). Pengaruh Pendekatan Saintifik Berorientasi Tri Kaya Parisudha Terhadap Penguasaan Konsep Ipa Dan Keterampilan Proses Sains Siswa Kelas V Sd Di Gugus Vii Kecamatan Sukasada Kabupaten Buleleng Tahun Pelajaran 2018/2019. Journal of Education Technology. https://doi.org/10.23887/jet.v3i1.17962. 
Syauqi, K., Munadi, S., \& Triyono, M. B. (2020). Students' perceptions toward vocational education on online learning during the COVID-19 pandemic. International Journal of Evaluation and Research in Education (IJERE), 9(4), 881. https://doi.org/10.11591/ijere.v9i4.20766.

Triyono. (2018). Teknik sampling dalam penelitian. XI(March), 2-9. https://doi.org/10.13140/RG.2.2.19674.24003.

Utami, T. N., Jatmiko, A., \& Suherman, S. (2018). Pengembangan Modul Matematika dengan Pendekatan Science, Technology, Engineering, And Mathematics (STEM) pada Materi Segiempat. Desimal: Jurnal Matematika, 1(2), 165. https://doi.org/10.24042/djm.v1i2.2388.

Wartono, W., Hudha, M. N., \& Batlolona, J. R. (2018). How are the physics critical thinking skills of the students taught by using inquiry-discovery through empirical and theorethical overview? Eurasia Journal of Mathematics, Science and Technology Education, 14(2), 691-697. https://doi.org/10.12973/ejmste/80632.

Wibowo, R., Widiati, U., \& Santoso, A. (2017). Bahan Ajar Tematik Materi Puisi Kelas V SD dengan Pemanfaatan Peta Pikiran dan Lingkungan sekitar. Jurnal Pendidikan: Teori, Penelitian, Dan Pengembangan, 2(6), 743-750. https://doi.org/10.17977/jptpp.v2i6.9324.

Widana, I. W. (2020). Pengaruh Pemahaman Konsep Asemen HOTS terhadap Kemampuan Guru Matematika SMA/SMK Menyusun Soal HOTS. Jurnal Emasains: Jurnal Edukasi Matematika Dan Sains, 9(1), 6675. https://doi.org/10.5281/zenodo.3743923.

Wirapathi, A., Candiasa, M., \& Suryawan, P. (2019). The development of transformation geometry learning edium with scientific approach as effort to improve the understanding concept skill. Journal of Education Technology, 2(2), 76. https://doi.org/10.23887/jet.v2i2.16185.

Yanto, F. (2019). Development of physics learning instructions using research based learning model with scientific approach. International Journal of Advanced Research, 7(3), 1238-1245. https://doi.org/10.21474/ijar01/8756.

Yodeska, Y. K., \& Nursaid, N. (2020). Struktur kalimat dan diksi teks eksposisi karya siswa kelas VIII SMP Negeri 12 Padang. Pendidikan Bahasa Indonesia, 8(3), 517. https://doi.org/10.24036/108242019883.

Yuanta, F. (2020). Pengembangan Media Video Pembelajaran Ilmu Pengetahuan Sosial pada Siswa Sekolah Dasar. Trapsila: Jurnal Pendidikan Dasar, 1(02), 91. https://doi.org/10.30742/tpd.v1i02.816.

Zulfiani, Suwarna, I. P., \& Sumantri, M. F. (2020). Science adaptive assessment tool: Kolb's learning style profile and student's higher order thinking skill level. Jurnal Pendidikan IPA Indonesia, 9(2), 194207. https://doi.org/10.15294/jpii.v9i2.23840. 